\title{
Evaluation of Hepatoprotective Activities Aqueous and Hydroethanolic Extracts from the Leaves of Erythrococca anomala in Rats
}

\author{
Miezan Bile Aka Patrice', Kouakou Sylvain Landry², Droucoula Guillaume Cyril ${ }^{1}$, \\ Kouakou-Syransy Giselle ${ }^{2}$, Koffi Akissi Jeanne ${ }^{1}$, Yapi Houphouet Felix ${ }^{1}$ \\ ${ }^{1}$ Laboratory of Biochemical Pharmacodynamics, UFR Biosciences, Felix Houphouet Boigny University, Abidjan, Ivory Coast \\ ${ }^{2}$ Department of Pharmacology, Clinical and Therapeutic Pharmacy UFR Pharmaceutical and Biological Sciences, Felix Houphouet Boigny \\ University, Abidjan, Ivory Coast
}

\section{Email address:}

Miezan.bile.aka.@gmail.com (M. B. A. Patrice)

\section{To cite this article:}

Miezan Bile Aka Patrice, Kouakou Sylvain Landry, Droucoula Guillaume Cyril, Kouakou-Syransy Giselle, Koffi Akissi Jeanne, Yapi Houphouet Felix. Evaluation of Hepatoprotective Activities Aqueous and Hydroethanolic Extracts from the Leaves of Erythrococca anomala in Rats. Advances in Biochemistry. Vol. 5, No. 4, 2017, pp. 61-66. doi: 10.11648/j.ab.20170504.12

Received: May 18, 2017; Accepted: May 31, 2017; Published: July 13, 2017

\begin{abstract}
Widely used in Ivory Coast and sub-Saharan Africa in traditional medicine as anti-inflammatory, antioxidant, laxative and purgative, Erythrococca anomala (Euphorbiaceae), is an annual plant. In this work, the aim was to evaluate the Hepatoprotective activity of the aqueous and hydroethanolic extracts of the leaves. Carbon Tetrachloride $\left(\mathrm{CCl}_{4}\right)$ was used to induce hepatotoxicity in rats. This hepatotoxic effect causes a significant increase in the levels of liver enzymes and serum proteins. Hepatoprotective activity was assessed by assaying liver enzymes such as serum transaminases (alanine aminotransferase and aspartate aminotransferase) and proteins by spectrophotometric and electrophoretic techniques. When administered orally as a preventive and curative dose of 100 and $200 \mathrm{mg} / \mathrm{kg}$ body weight, the extracts significantly reduce significantly as silymarin, the reference hepatoprotective substance at $100 \mathrm{mg} / \mathrm{kg}$ bw, hepatotoxicity induced by Carbon tetrachloride $\left(\mathrm{CCL}_{4}\right)$ at a dose of $5 \mathrm{mg} / \mathrm{kg}$ bw after a significant reduction in liver enzyme levels, globulins and a significant increase in albumin. The possible mechanism of this hepatoprotective activity of the extracts may be due to the action of the antioxidants such as the flavonoids, the phenols present in the extracts.
\end{abstract}

Keywords: Erythrococca anomala, Silymarin, Carbon Tetrachloride, Hepatotoxicity, Hepatoprotective

\section{Introduction}

Medicinal plants are widely used in traditional medicine for the prevention and treatment of various diseases, especially in sub-Saharan Africa and in developing countries [1]. These plants currently constitute reservoirs of natural substances used in the treatment of many infections [2]. It is therefore necessary to look for highly effective, low toxic, low-cost herbal remedies [3].

Erythrococca anomala is a medicinal plant of the family Euphorbiaceae, widely used in traditional medicine in Ivory Coast and sub-Saharan Africa. Phytochemical studies have revealed the presence of phenols, flavonoids, alkaloids, sterols and saponosides in leaves [4]. These various secondary metabolites hold the attention of playing an essential role in the treatment of diseases [5]. Similarly, studies have shown that the leaves have anti-inflammatory and antioxidant activity [6, 7].

In Ivory Coast, the macerates of the leaves of this plant make it possible to fight against meningitis and malaria, while in Cameroon, decoctions and macerated leaves allow to treat dental pain; But used as laxatives and purgatives, make it possible to expel the worms; in Nigeria, bark is used against arthritis and rheumatism [8].

However, there is no information on the hepatoprotective properties of the leaves of this plant.

This study aims to evaluate the hepatoprotective activities of aqueous and hydroethanolic extracts of the leaves of Erythrococca anomala by the determination of hepatic enzymes such as serum transaminases (alanine 
aminotransferase and aspartate aminotransferase) and proteins by spectrophotometric and electrophoretic techniques.

\section{Materials and Methods}

\subsection{Equipment}

\subsubsection{Plant Material}

The plant material consists of leaves of Erythrococca anomala harvested in the Yakssé-mé region, Department of Adzopé, $15 \mathrm{~km}$ from Abidjan, washed and dried at room temperature, protected from the sun at the research laboratory of Inorganic and organic chemistry of the UFR of pharmaceutical and biological sciences. This plant has been identified at the National Floristic Center of Ivory Coast where a sample (OAT -ErAn) is kept.

\subsubsection{Animal Equipment}

Wistar albinos rats weighing 190-200 g of each sex kept for three weeks at the laboratory animal home of UFR Pharmaceutical and Biologic Sciences, University of Felix Houphouet Boigny, Ivory Coast were used. The animals were maintained under standard housing conditions: temperature $\left(27^{\circ} \pm 1 \mathrm{C}\right)$, humidity $(55-60 \%)$, light/dark cycle $(12: 12 \mathrm{~h})$ and had free access to standard rodent pellet diet and water ad libitum.

\subsection{Methods}

\subsubsection{Preparation of Extracts}

The aqueous extract is prepared from 100 grams of Erythrococca anomala leaf powder in one liter of boiling distilled water for fifteen minutes. The solution thus obtained is filtered on hydrophilic cotton and then vacuumed with ordinary filter paper. The collected filtrate was placed in an oven at $40^{\circ} \mathrm{C}$. A dark brown dry powder was obtained for the total crude aqueous extract of Erythrococca anomala.

The Guédé-Guina method [9] was used to obtain the $70 \%$ hydroethanolic extract of Erythrococca anomala. A 70\% hydroethanolic solution (Et $\mathrm{OH} / \mathrm{H}_{2} \mathrm{O}, 70$ : 30) was used for the preparation of Hydroethanolic extract of Erythrococca anomala in a vial. One liter of the hydroethanolic solution and $100 \mathrm{~g}$ of Erythrococca anomala powder were used for this purpose. The mixture obtained was homogenized with a magnetic stirrer for 24 hours. The homogenate is filtered on hydrophilic cotton and then under vacuum. The collected filtrate was concentrated in a rotary evaporator and then placed in an oven at $40^{\circ} \mathrm{C}$. for complete drying. The $70 \%$ hydroethanolic extract of Erythrococca anomala appears in the form of a dark green paste after drying.

\subsubsection{Preventive Treatment}

The determination of the Hepatoprotective properties of the extracts was carried out according to the method described by [10] with some modifications. It is a method that demonstrates the preventive properties of aqueous and hydroethanolic extracts of leaves of Erythrococca anomala against carbon tetrachloride $\left(\mathrm{CCL}_{4}\right)$ poisoning in comparison with silymarin (Sil).
The animals received the following treatments:

- Lot 1 received distilled water for 7 days and then $5 \mathrm{ml} /$ $\mathrm{kg}$ bw of $\mathrm{CCl}_{4}$ poisoning solution intraperitoneally on the seventh day of treatment.

- Lot 2 received Olive Oil for 7 days by intraperitoneal on the seventh day.

- Lot 3 received silymarin (Sil) at $100 \mathrm{mg} / \mathrm{kg}$ bw for 7 days then $5 \mathrm{ml} / \mathrm{kg}$ bw of the $\mathrm{CCl}_{4}$ intoxication solution by intraperitoneal route on the seventh day of treatment.

The rats of batches 4 and 5 respectively received 100 and $200 \mathrm{mg} / \mathrm{kg}$ bw of aqueous extract for 7 days then $5 \mathrm{ml} / \mathrm{kg}$ bw of the $\mathrm{CCl}_{4}$ intoxication solution by intraperitoneal route on the seventh day of treatment.

The rats of batches 6 and 7 received respectively 100 and $200 \mathrm{mg} / \mathrm{kg}$ of hydroethanolic extract for 7 days then $5 \mathrm{ml} /$ $\mathrm{kg}$ bw of the $\mathrm{CCl}_{4}$ intoxication solution by intraperitoneal route on the seventh day of treatment.

\subsubsection{Curative Treatment}

The curative treatment demonstrates the curative properties of aqueous and hydroethanolic extracts of the leaves of Erythrococca anomala in comparison with that of Sil

- Lot 9 received $5 \mathrm{~mL} / \mathrm{kg}$ bw of $\mathrm{CCl}_{4}$ intraperitoneally for 7 days.

- Lot 10 received Olive Oil per os for 7 days.

- Lot 11 received intramuscularly $5 \mathrm{~mL} / \mathrm{kg}$ bw of $\mathrm{CCl}_{4}$ per day for 3 days followed by silymarin (Syl) at $100 \mathrm{mg} / \mathrm{kg}$ bw per os for 4 days.

The rats of lots 12 and 13 received intramuscularly $5 \mathrm{ml} / \mathrm{kg}$ bw of $\mathrm{CCl}_{4}$ per day for 3 days and then $100 \mathrm{mg} / \mathrm{kg}$ and 200 $\mathrm{mg} / \mathrm{kg}$ bw of the aqueous extract of the leaves of Erythrococca anomala per os, during 4 days.

The rats of batches 14 and 15 received intramuscularly $5 \mathrm{~mL}$ $/ \mathrm{kg}$ bw of $\mathrm{CCl}_{4}$ per day for 3 days and $100 \mathrm{mg} / \mathrm{kg}$ and 200 $\mathrm{mg} / \mathrm{kg}$ bw of the hydroethanolic extract of the leaves of Erythrococca anomala per os, during 4 days.

Blood was collected by caudal puncture on day 8 to estimate serum levels of transaminases (Aspartate Aminotransferase (ASAT), Alanine Aminotransferase (ALAT)), proteins and globins by electrophoresis.

\subsubsection{Statistical Analysis}

The values expressed as mean \pm SD from 6 animals. The results were subjected to statistical analysis by using one way ANOVA followed by Dunnett's test to significant, $p$ values less than 0.05 were considered significant.

\section{Results}

\subsection{Preventive Effect of Different Extracts on the Concentrations of Transaminases and Total Proteins During Hepatotoxicity}

The results of the assay show that before the experiment (D0) there was no significant difference in the concentration of aspartate aminotransferase (ASAT), alanine aminotransferase (ALAT) and total proteins (PRO) between the different Lots. After 7 days of experiments, the assay 
showed that $\mathrm{CCl}_{4}$ increased transaminase concentrations and decreased the total proteins in the untreated intoxication batch (distilled water $\left.+\mathrm{CCl}_{4}\right)$ significantly $(p<0.001)$ compared to that of the non-intoxicated batch Treated Olive Oil, intoxicated by Silymarin (Sil) and aqueous and hydroethanolic extracts of the leaves of Erythrococca anomala (Table 1).

In general, the preventive effect of aqueous and hydroethanolic extracts of the leaves of Erythrococca anomala over concentrations of aspartate aminotransferase (ASAT), alanine aminotransferase (ALAT) and total proteins (PRO) is similar to that of Sil (Table 1).

Table 1. Preventive effect of extracts on the concentrations of transaminases and total proteins during hepatotoxicity.

\begin{tabular}{|c|c|c|c|c|c|c|}
\hline \multirow{2}{*}{ TREATMENT } & \multicolumn{3}{|l|}{ DO } & \multicolumn{3}{|l|}{ D7 } \\
\hline & ASAT (UI/L) & ALAT (UI/L) & TOTAL PROT (g/L) & ASAT (UI/L) & ALAT (UI/L) & TOTAL PROT (g/L) \\
\hline Olive Oil & $259.7 \pm 19,63$ & $229.3 \pm 19$ & $82 \pm 35.54$ & $259.7 \pm 4.0 * * *$ & $228.5 \pm 35,54 * *$ & $83.8 \pm 37.17 * * *$ \\
\hline Water+ $\mathrm{CCl}_{4}$ & $222.3 \pm 27.43$ & $206.3 \pm 5.68$ & 88.675 .5 & $372 \pm 22.5$ & $389.54 \pm 5.85$ & $39.7 \pm 5.03$ \\
\hline $\mathrm{Sil}+\mathrm{CCl}_{4}$ & $252 \pm 38.69$ & $224.67 \pm 9.07$ & $83.33 \pm 16.86$ & $258 \pm 9.6 * * *$ & $226.67 \pm 19.2 * * *$ & $80.67 \pm 33 * * *$ \\
\hline A. E $100 \mathrm{mg} / \mathrm{kg}+\mathrm{CCl}_{4}$ & $238 \pm 86.03$ & $229.3 \pm 1.52$ & $82.14 \pm 2,03$ & $271.3 \pm 8.61 * *$ & $227.49 \pm 3.2 * * *$ & $78.47 \pm 3.7 * * *$ \\
\hline A. E $200 \mathrm{mg} / \mathrm{kg}+\mathrm{CCl}_{4}$ & $227 \pm 20.3$ & $223 \pm 49.96$ & $82.4 \pm 2.22$ & $253.3 \pm 10.2 * * *$ & $225.33 \pm 5.8 * * *$ & $79.86 \pm 3.8 * * *$ \\
\hline H. E $100 \mathrm{mg} / \mathrm{kg}+\mathrm{CCl}_{4}$ & $246 \pm 24.56$ & $226 \pm 31.61$ & $83.08 \pm 3.94$ & $287.3 \pm 9.25 * *$ & $230.93 \pm 10.4 * * *$ & $77.81 \pm 1.9 * * *$ \\
\hline H. E $200 \mathrm{mg} / \mathrm{kg}+\mathrm{CCl}_{4}$ & $254.7 \pm 17.67$ & $227 \pm 41.55$ & $81.47 \pm 3.83$ & $275.7 \pm 5.50 * *$ & $228.93 \pm 17.8 * * *$ & $78.12 \pm 0.78 * * *$ \\
\hline
\end{tabular}

E. A= Aqueous Extract; E. H= Hydroethanolic Extract. Each value was the average \pm SD, N $=6$ rats, the data were analyzed by One Way ANOVA followed by the Dunnett test $* * * p<0.001, * * p<0.01$ where the extracts, olive Oil and silymarin (Sil) were compared with water $+\mathrm{CCl}_{4}$.

\subsection{Curative Effect of Extracts on the Concentrations of Transaminases and Total Proteins During Hepatotoxicity}

The results of the assay show that before the experiment (D0) there was no significant difference in the concentrations of aspartate aminotransferase (ASAT), alanine aminotransferase (ALAT) and total proteins (PRO) between different lots.

After 7 days of experiments, the assay shows that $\mathrm{CCl}_{4}$ increases transaminase concentrations and decreases the total protein in the untreated intoxication lot (distilled water + $\left.\mathrm{CCl}_{4}\right)$ significantly $(p<0.001)$ compared to that of the nonintoxicated lot, Untreated with olive oil, intoxicated with Silymarin (Sil) and aqueous and hydroethanolic extracts of the leaves of Erythrococca anomala (Table 2). In general, the curative effect of aqueous and hydroethanolic extracts of the leaves of Erythrococca anomala on the serum concentration of aspartate aminotransferase (ASAT), alanine aminotransferase (ALAT) and total proteins (PRO) is similar to that of Sil (Table 2).

Table 2. Curative effect of extracts on the concentrations of transaminases and total proteins during hepatotoxicity.

\begin{tabular}{lllllll}
\hline \multirow{2}{*}{ TREATMENT } & DO & \multicolumn{5}{l}{ D7 } \\
\cline { 2 - 7 } & ASAT (UI/L) & ALAT (UI/L) & TOTAL PROT (UI/L) & ASAT (UI/L) & ALAT (UI/L) & TOTAL PROT (UI/L) \\
\hline Olive Oil & $259.7 \pm 19.63$ & $241 \pm 37.32$ & $82 \pm 35.54$ & $240.7 \pm 7.5^{* * *}$ & $242 \pm 35.54^{* * *}$ & $84.8 \pm 37.17^{* * *}$ \\
Water $+\mathrm{CCl}_{4}$ & $252.3 \pm 27.43$ & $242.3 \pm 5.68$ & 82.675 .5 & $324.8 \pm 22.5$ & $389.54 \pm 5.85$ & $38.7 \pm 5.03$ \\
Sil $+\mathrm{CCl}{ }_{4}$ & $253 \pm 38.69$ & $244.67 \pm 9.07$ & $83.33 \pm 16.86$ & $247.5 \pm 9.6^{* * *}$ & $248.67 \pm 19.2^{* * *}$ & $82.67 \pm 33^{* * *}$ \\
A. E $100 \mathrm{mg} / \mathrm{kg}+\mathrm{CCl}_{4}$ & $258 \pm 86.03$ & $241.3 \pm 1.52$ & $81.14 \pm 2.03$ & $248.3 \pm 7.5^{* * *}$ & $247.49 \pm 3.2^{* * *}$ & $79.47 \pm 3.7^{* * *}$ \\
A. E $200 \mathrm{mg} / \mathrm{kg}+\mathrm{CCl}_{4}$ & $257 \pm 20.3$ & $240.7 \pm 49.96$ & $84.4 \pm 2.22$ & $245.3 \pm 15.8^{* * *}$ & $246.33 \pm 5.8^{* * *}$ & $81.86 \pm 3.8^{* * *}$ \\
$\mathrm{H} . \mathrm{E} 100 \mathrm{mg} / \mathrm{kg}+\mathrm{CCl}_{4}$ & $256 \pm 24.56$ & $241.8 \pm 31.61$ & $83.08 \pm 3.94$ & $249.3 \pm 7.3^{* * *}$ & $249.93 \pm 10.4^{* * *}$ & $78.81 \pm 1.9^{* * *}$ \\
$\mathrm{H} . \mathrm{E} 200 \mathrm{mg} / \mathrm{kg}+\mathrm{CCl}_{4}$ & $255.7 \pm 17.67$ & $247.9 \pm 41.55$ & $85.47 \pm 3.83$ & $247.3 \pm 5.80^{* * *}$ & $248.93 \pm 17.8^{* * *}$ & $82.12 \pm 0.78^{* * *}$ \\
\hline
\end{tabular}

A. $E=$ Aqueous Extract; H. E $=$ Hydroethanolic Extract. Each value was the average \pm SD, $N=6$ rats, data were analyzed by One Way ANOVA followed by the Dunnett test $* * * p<0.001$; Where the extracts, olive Oil and silymarin (Sil) were compared with water $+\mathrm{CCl}_{4}$.

\subsection{Preventive Effect of Different Treatments on Protein Electrophoresis}

The results of protein electrophoresis show that before the experiment (D0) there was no significant difference in the concentration of the globulins and the albumin between the different batches.

After 7 days of experience, protein electrophoresis showed that $\mathrm{CCl}_{4}$ increased globulin concentrations and decreased albumin in the untreated intoxicated lots $\left(\right.$ distilled water $\left.+\mathrm{CCl}_{4}\right)$ significantly $(p<0.001)$ compared to that of the non-intoxicated lot untreated Olive Oil, intoxicated by Silymarin (Sil) and the aqueous and hydroethanolic extracts of the leaves of Erythrococca anomala.

This increase was corroborated by the albumin / Globulin (Alb / Glb) ratio, which significantly decreases $(p<0.001)$ in the untreated intoxication batch (Distilled water $+\mathrm{CCl}_{4}$ ) compared to the other batches (Table 3 ).

In general, the preventive effect of aqueous and hydroethanolic extracts of leaves of Erythrococca anomala on protein electrophoresis is similar to that of Sil. 
Table 3. Preventive effect of extracts on serum protein electrophoresis during hepatotoxicity.

\begin{tabular}{lllllll}
\hline \multirow{2}{*}{ Treatments } & D0 & & & & & \\
\cline { 2 - 7 } & Alb & $\boldsymbol{\alpha}_{\mathbf{1}}$ Glb & $\boldsymbol{\alpha}_{\mathbf{2}}$ Glb & BGlb & $\boldsymbol{\gamma}$ Glb & Alb/Glb \\
\hline Olive Oil & $23.70 \pm 3.5$ & $8.5 \pm 2.3$ & $9.3 \pm 5.16$ & $9.33 \pm 3.8$ & $15.5 \pm 7.6$ & 0.55 \\
Water+CCl4 & $24.58 \pm 2.9$ & $7.53 \pm 6.2$ & $8.93 \pm 0.1$ & $8.73 \pm 1.3$ & $14.97 \pm 5.1$ & 0.61 \\
Sil+CC14 & $23.57 \pm 0.4$ & $8.33 \pm 3$ & $7.6 \pm 3.5$ & $9.96 \pm 1.0$ & $15.1 \pm 3.13$ & 0.57 \\
A. E $100 \mathrm{mg} / \mathrm{kg}+\mathrm{CCl} 4$ & $24.17 \pm 1.2$ & $7.1 \pm 3.3$ & $8.15 \pm 1.3$ & $10.23 \pm 4$ & $13.30 \pm 5$ & 0.62 \\
A. E $200 \mathrm{mg} / \mathrm{kg}+\mathrm{CCl} 4$ & $25.63 \pm 1.6$ & $9.11 \pm 2.7$ & $7.7 \pm 37$ & $9.7 \pm 3.6$ & $14.27 \pm 13$ & 0.62 \\
H. E $100 \mathrm{mg} / \mathrm{kg}+\mathrm{CCl} 4$ & $24.98 \pm 1.6$ & $8.13 \pm 4.1$ & $8.6 \pm 2.5$ & $8.00 \pm 1.8$ & $13.37 \pm 2.6$ & 0.65 \\
H. E 200 $\mathrm{mg} / \mathrm{kg}+\mathrm{CCl} 4$ & $27.90 \pm 5.1$ & $7.1 \pm 3.7$ & $9.6 \pm 2.1$ & $10.5 \pm 0.7$ & $12.8 \pm 3.6$ & 0.70 \\
\hline
\end{tabular}

Table 3. Continue.

\begin{tabular}{lllllll}
\hline \multirow{2}{*}{ Treatments } & D7 & & & & \\
\cline { 2 - 7 } & Alb & $\alpha_{1}$ Glb & $\alpha_{2}$ Glb & $\beta$ Glb & $\gamma$ Glb & Alb/Glb \\
\hline Olive Oil & $23.47 \pm 1^{* * *}$ & $8.0 \pm 1^{* * *}$ & $9.73 \pm 3^{* *}$ & $9.73 \pm 1^{* * *}$ & $15.6 \pm 5^{* *}$ & $0.55^{* * *}$ \\
Water+CCl4 & $11.45 \pm 3.04$ & $18.4 \pm 1,5$ & $16.47 \pm 2.1$ & $19.13 \pm 2$ & $27.33 \pm 5$ & 0.14 \\
Sil+CCl4 & $22.13 \pm 3^{* * *}$ & $10.5 \pm 5^{* * *}$ & $9.43 \pm 2^{* * *}$ & $10.9 \pm 4^{* * *}$ & $17.36 \pm 4^{* * *}$ & $0.45^{* * *}$ \\
A. E $100 \mathrm{mg} / \mathrm{kg}+\mathrm{CCl} 4$ & $21.13 \pm 8^{* * *}$ & $9.0 \pm 4^{* * *}$ & $10.5 \pm 2^{* * *}$ & $12 \pm 0.95^{* *}$ & $16.6 \pm 5^{* * *}$ & $0.43^{* * *}$ \\
A. E $200 \mathrm{mg} / \mathrm{kg}+\mathrm{CCl} 4$ & $23.4 \pm 0.7^{* * *}$ & $11.1 \pm 5^{* * *}$ & $9.3 \pm 3^{* * *}$ & $10.7 \pm 2^{* * *}$ & $15.5 \pm 14^{* * *}$ & $0.50^{* * *}$ \\
H. E $100 \mathrm{mg} / \mathrm{kg}+\mathrm{CCl} 4$ & $21.17 \pm 1^{* * *}$ & $9.9 \pm 0.5^{* * *}$ & $10.6 \pm 2^{* * *}$ & $11.9 \pm 1^{* * *}$ & $15.92 \pm 5^{* * *}$ & $0.43^{* * *}$ \\
H. E $200 \mathrm{mg} / \mathrm{kg}+\mathrm{CCl} 4$ & $22.0 \pm 1.4^{* * *}$ & $8.5 \pm 0.3^{* * *}$ & $9.8 \pm 1^{* * *}$ & $10.7 \pm 4^{* * *}$ & $14.17 \pm 1^{* * *}$ & $0.50^{* * *}$ \\
\hline
\end{tabular}

A. $E=$ Aqueous Extract; H. E = Hydroethanolic Extract. Each values was average $\pm \mathrm{SD} ; \mathrm{N}=6$ rats; data were analyzed by one way Anova following the Dunnett test ${ }^{* * *} p<0.01$. Where the extracts olive oil and control the distilled water was compared with silymarin $(\mathrm{Sil}) . \alpha_{1} \mathrm{Glb}=\alpha_{1} \mathrm{Globulin} ; \alpha_{2} \mathrm{Glb}=$ $\alpha_{2}$ Globulin; $\beta \mathrm{Glb}=\beta \mathrm{Globulin} ; \gamma \mathrm{Glb}=\gamma \mathrm{Globulin} ; \mathrm{Alb}=$ Albumin; $\mathrm{Alb} / \mathrm{Glb}=$ Ratio Albumin $/$ Globulin .

\subsection{Curative Effect of Different Treatments Protein Electrophoresis}

The results of protein electrophoresis show that before the experiment (D0) there was no significant difference in the concentration of the globulins and the albumin between the different lots. After 7 days of experience, protein electrophoresis showed that $\mathrm{CCl}_{4}$ increased globulin concentrations and decreased albumin in the untreated intoxication lots (Distilled water $+\mathrm{CCl}_{4}$ ) significantly $(p$ $<0.01)$ compared with To that of the non-intoxicated

Table 4. Curative effect of extract on protein electrophoresis during hepatotoxicity. untreated lot Olive Oil, intoxicated treated with Silymarin (Sil) and the aqueous and hydroethanolic extracts of the leaves of Erythrococca anomala.

This increase was corroborated by the albumin / Globulin (Alb / Glb) ratio, which decreased significantly $(p<0.01)$ in the untreated intoxicated batch (Distilled Water $+\mathrm{CCl}_{4}$ ) compared to the other batches (Table 4).

In general, the curative effect of aqueous and hydroethanolic extracts of Erythrococca anomala leaves on protein electrophoresis is similar to that of Sil.

\begin{tabular}{|c|c|c|c|c|c|c|}
\hline \multirow{2}{*}{ Traitements } & \multicolumn{6}{|l|}{ D0 } \\
\hline & Alb & $\alpha_{1}$ Glb & $\alpha_{2}$ Glb & BGIb & $\gamma$ Glb & Alb/Glb \\
\hline Olive Oil & $23.70 \pm 3.5$ & $8.5 \pm 2.3$ & $9.3 \pm 5.16$ & $9.33 \pm 3.8$ & $15.5 \pm 7.6$ & 0.55 \\
\hline Water+CCl4 & $24.58 \pm 2.9$ & $7.53 \pm 6.2$ & $8.93 \pm 0.1$ & $8.73 \pm 1.3$ & $14.97 \pm 5.1$ & 0.61 \\
\hline $\mathrm{Sil}+\mathrm{CCl} 4$ & $23.57 \pm 0.4$ & $8.33 \pm 3$ & $7.6 \pm 3.5$ & $9.96 \pm 1.0$ & $15.1 \pm 3.13$ & 0.57 \\
\hline A. $\mathrm{E} 100 \mathrm{mg} / \mathrm{kg}+\mathrm{CCl} 4$ & $24.17 \pm 1.2$ & $7.1 \pm 3.3$ & $8.15 \pm 1.3$ & $10.23 \pm 4$ & $13.30 \pm 5$ & 0.62 \\
\hline A. E $200 \mathrm{mg} / \mathrm{kg}+\mathrm{CCl} 4$ & $25.63 \pm 1.6$ & $9.11 \pm 2.7$ & $7.7 \pm 3.7$ & $9.7 \pm 3.6$ & $14.27 \pm 13$ & 0.62 \\
\hline H. E $100 \mathrm{mg} / \mathrm{kg}+\mathrm{CCl} 4$ & $24.98 \pm 1.6$ & $8.13 \pm 4.1$ & $8.6 \pm 2.5$ & $8.00 \pm 1.8$ & $13.37 \pm 2.6$ & 0.65 \\
\hline H. Е $200 \mathrm{mg} / \mathrm{kg}+\mathrm{CCl} 4$ & $27.90 \pm 5.1$ & $7.1 \pm 3.7$ & $9.6 \pm 2.1$ & $10.5 \pm 0.7$ & $12.8 \pm 3.6$ & 0.70 \\
\hline
\end{tabular}

Table 4. Continue.

\begin{tabular}{|c|c|c|c|c|c|c|}
\hline \multirow{2}{*}{ Traitements } & \multicolumn{6}{|l|}{ D7 } \\
\hline & Alb & $\alpha_{1}$ Glb & $\alpha_{2}$ Glb & BGIb & $\gamma$ GIb & Alb/Glb \\
\hline Olive Oil & $25,47 \pm 1,8^{* *}$ & $9,60 \pm 5^{* *}$ & $10,4 \pm 35^{* *}$ & $9,53 \pm 3 * *$ & $11,8 \pm 5^{* *}$ & $0,60 * *$ \\
\hline Water+CCl4 & $19,32 \pm 2,4$ & $18,4 \pm 1,5$ & $17,53 \pm 2,1$ & $18,15 \pm 2,8$ & $19,37 \pm 5 * *$ & $0,26 * *$ \\
\hline $\mathrm{Sil}+\mathrm{CCl} 4$ & $29,83 \pm 3,2 * *$ & $10,56 \pm 1 * *$ & $12,4 \pm 2 * *$ & $11,1 \pm 4 * *$ & $12,27 \pm 3 * *$ & $0,64 * *$ \\
\hline A. E100 mg/kg+CCl4 & $29,15 \pm 0,1 * *$ & $10,16 \pm 4 * *$ & $12,5 \pm 2 * *$ & $12,5 \pm 3 * *$ & $13,9 \pm 7 * *$ & $0,59 * *$ \\
\hline A. E $200 \mathrm{mg} / \mathrm{kg}+\mathrm{CCl} 4$ & $28,4 \pm 0,8 * *$ & $12,1 \pm 0,5^{* *}$ & $11,2 \pm 3 * *$ & $10,3 \pm 2 * *$ & $12,5 \pm 15^{* *}$ & $0,61 * *$ \\
\hline H. E $100 \mathrm{mg} / \mathrm{kg}+\mathrm{CCl} 4$ & $26,27 \pm 2,4^{* *}$ & $10 \pm 0,2 * *$ & $13,63 \pm 2 * *$ & $13,96 \pm 1 * *$ & $13,2 \pm 5 * *$ & $0,51 * *$ \\
\hline
\end{tabular}

A. E= Aqueous Extract; H. E= Hydroethanolic Extract. Each values was average \pm SD; N= 6 rats; data were analyzed by one way Anova following the Dunnett test $* * * p<0.01$. Where the extracts olive oil and control the distilled water was compared with silymarin $($ Sil $)$. $\alpha_{1}$ Glb $=\alpha_{1} \mathrm{Globulin} ; \alpha_{2} \mathrm{Glb}=$ $\alpha_{2}$ Globulin; $\beta \mathrm{Glb}=\beta \mathrm{Globulin} ; \gamma \mathrm{Glb}=\gamma \mathrm{Globulin} ; \mathrm{Alb}=$ Albumin; Alb/ Glb = Ratio Albumin $/$ Globulin. 


\section{Discussion}

The results of the preventive and curative tests are similar in general and show that the treatment with aqueous and hydroethanolic extracts of the leaves of Erythrococca anomala protect the liver and repair the lesions caused by $\mathrm{CCl}_{4}$. The protective effects of the various extracts were due to an increase in the activity of the antioxidant enzymes. Indeed, $\mathrm{CCl}_{4}$ is a dose-dependent hepatotoxic and its toxicity is mainly due to the appearance of free radicals or toxic forms of oxygen which induce lipid peroxidation leading to the destruction of cell membranes. The increase in serum levels of transaminases, total proteins, globulins and decreased serum albumin after $\mathrm{CCl}_{4}$ injection is evidence of significant hepatic involvement. $\mathrm{CCl}_{4}$ induced hepatic injury is commonly used as a model for liver drug screening and the extent of damage is assessed by the level of cytoplasmic transaminases (ALAT and ASAT), total proteins, globulins, and albumin [11]. The reduction in the level of liver enzymes, globulins and albumin, total protein, albumin / globulin ratio by extracts is an indicator of the regeneration of the repair process of the lesions of the liver. [12]. These results corroborate those of the studies, which reported that transaminases and serum proteins are restored with hepatocyte regeneration and hepatic parenchyma restructuring [13].

It has been shown that the ability of hepatoprotective substances to reduce the harmful effects or preserve the mechanisms of liver functioning against hepatotoxin disturbances is an indication of their protective effect. [13]. It can therefore assert that repeated administration of the aqueous and hydroethanolic extracts of Erythrococca anomala leaves protect against the hepatotoxicity caused by $\mathrm{CCl}_{4}$ with an efficiency close to that of Sil. Since, as a result of $\mathrm{CCl}_{4}$ induced lesions, it is seeing a substantial increase in the values of ASAT, ALAT, and globulins. A decrease in albumin and total protein levels, which is a clear sign of cell lysis and loss of functional integrity of the hepatocyte membrane, the decrease in $\mathrm{CCl}_{4}$-induced morphological lesions may be a sign of repair of the hepatocytes, a reinforcement of the parenchyma, following the treatment with the extracts. The decrease in ASAT serum levels, of ALAT, globulins, and increased albumin and total protein levels is therefore indicative of an improvement in liver function. This work has shown that the aqueous and hydroethanolic extracts of the leaves of Erythrococca anomala act as preventive as well as curative. Flavonoids and phenols are recognized for their hepatoprotective activities [14]. The antioxidant and hepatoprotective activities of these extracts can therefore be due to the presence of flavonoids and phenols.

\section{Conclusion}

The work performed in this study confirmed the hepatotoxic effect of $\mathrm{CCl}_{4}$. Its effects result in cell lysis and loss of functional integrity of the hepatocyte membrane following the intensive production of free radicals causing an increase in enzymes, globulins and a decrease in hepatic proteins and albumin. Aqueous, hydroethanolic extracts and silymarin (a reference hepatoprotectant) play a protective role in the oxidative stress produced in the liver by $\mathrm{CCl}_{4}$ by decreased enzymes, globulins and increased protein and albumin. The results show that the protective effect of the aqueous and hydroethanolic extracts of the leaves of Erythrococca anomala is due to the antioxidant phenolic compounds free radical scavengers that protect the hepatocytes against the oxidizing effect of $\mathrm{CCl}_{4}$.

\section{Acknowledgments}

The authors are grateful to Kouamé Yao Yao Germain who translates the manuscript in english. Thank you.

\section{References}

[1] R. Islam, A. H. Alam, B. M. Rahman, K. A. Salam, A. Hossain, A. Baki, G. Sadik. Toxicological studies of two compounds isolated from Loranthus globosusRoxb. Pak. J. Biol. Sci., 10(2007) 2073-2077.

[2] D. Kubmarawa, G. A. Ajoku, N. M. Enwerem, D. A. Okorie. Preliminaryphytochimical and antimicrobial screening of 50 medecinal plants from Nigeria, Afr. J. Biotechnol., 6 (2007) 1690-1696.

[3] F. Calzada, L. Yepez-Mulia, A. Tapia-Contreras. Effect of Mexicanmedecinal plant used to treat tricomoniasis on Trichomonas vaginalistrophozoites. J. Ethnopharmacol. 113 (2007) 248-251.

[4] Miezan BAP, Okpekon AT, Yapi HF, Bony FN, Gbassi G, Assi YJ. Chemical component and acute toxicity study of Erythrococca anomala (Euphorbiaceae). Asian Journal of Biomedical and Pharmaceutical Sciences. 2016; 6(57): 4-8. 5.

[5] Oladele GM, Abatan MO, Olukynle JO, Okediran BS. Antiinflammatory and analgesic effect of aqueous leafextracts of Gomphrenacelosioides and Momordicacharinda. J Nat. Sat. Sci. Engr. Tech. 2009; 8(2): 1-8.6.

[6] Patrice M BA, Yapi HF, Opkekon AT, Bony FN, KouakouSiransy G, Kouakou YébouéKF. Evaluation of antiinflammatory activities of Erythrococca anomalaaqueous and ethanolic extracts from leaves in rat. 14(2): 1-7, 2016; IJBCRR. 28385.

[7] Miezan BAP, Okpekon AT, Koukou SL, Droucoula GC, Yapi HF. Evaluation of Antioxidant Activities of Erythrococca anomala Aqueous and Hydroethanolic Extracts. Journal ofBiotechnology and Biochemistry. Volume3, (2017), 113-118.

[8] Adjanohoun EJ, Ake-Assi L. Contribution au recensement des plantes médicinales de Côte d'Ivoire. Centre National de Floristique de l'Université Nationale de Côte d'Ivoire, Tome 1, 23-30. Lavoisier, Paris. 1979; 895.

[9] Guédé FG. Extraction of mansoninfromMansoniaaltissimaas cardiovascular agent (patent application) 1990. Ministère de la Recherche Scientifique, Côte d'Ivoire. 35 pp. 
[10] Raj, S., and Gothandam, K. M. (2014). Hepatoprotectiveeffect of polyphenolsrichmethanolic extract of Amorphophallus commutatus var. wayanadensisagainst $\mathrm{CCl} 4$ induced hepaticinjury in swissalbinomice. Food Chem. Toxicol. 67, 105-112. doi: 10.1016/j.fct.2014. 02.028.

[11] Hegde K., A. B. Joshia. (2009). Hepatoprotective effect of Carissa carandas root extract against $\mathrm{CCl}_{4}$ and paracetamol induced hepatic oxidative stress. India J. Exp. Biol., 47: 660667.
[12] Suresh K. S. V. \& Mishra S. H. (2008). Hepatoprotective effect of Pergulariadaemia (Forsk.) ethanol extract and it fraction. Indian. J. Exp. Biol. 46(6): 447-452.

[13] Krishna K. L., Mruthunjaya K., Patel J. A. (2010). Antioxidant and hepatoprotective potential of stem methanolic extract of JusticiagendarussaBurm. Int. J. Pharma. 67: 2-80.

[14] Wegner S. T\&Fintelmamann V. (1999). Pharmacological properties and therapeutic profile of artichoke (Cynarascolymus L.). Wien Med Wochenschr. 149: 241-247. 